\title{
Hisse Senedi Piyasalarının Zayıf Form Piyasa Etkinliğinin Küresel Ölçekte Karşılaştırılması: G-20 Üyeleri Üzerine Ampirik Bir Çalışma
}

\author{
Oktay Özkanª, b
}

\section{Özet}

$\mathrm{Bu}$ çalışma,G-20 üyelerini hisse senedi endekslerinin 07.06.2009 ve 09.02.2020 tarihleri arasındaki haftalık verilerini kullanarak G-20 üyelerinin hisse senedi piyasalarının getiri öngörülebilirliğini, diğer bir ifadeyle zayıf formdaki piyasa etkinliğini karşılaştırma açısından analiz etmektedir. Kim (2009) tarafından geliştirilen doğal bootstrap otomatik varyans oranı testi analizleri neticesinde, Brezilya, Güney Afrika ve Almanya hisse senedi piyasalarının çalışma kapsamındaki tarih aralığında zayıf formda etkin olduğu, dolayısıyla getirilerin öngörülemez olduğu, diğer piyasaların ise zayıf form etkinliğinin (getiri öngörülebilirliğin) periyodik olarak değiştiği bulunmuştur. Brezilya, Güney Afrika ve Almanya'ya ek olarak, Rusya, Fransa, İtalya, ABD, İngiltere ve Kanada hisse senedi piyasalarında tarihsel fiyat hareketleri veya getirileri ile getirilerin tahmin edilebilme şansı oldukça düşüktür. Ayrıca Japonya, Avustralya, Çin, Suudi Arabistan ve özellikle Meksika hisse senedi piyasalarının getiri öngörülebilirlik dönemlerinin diğer piyasalardan daha yüksek olduğu ve bu piyasalarda tarihsel fiyat bilgilerini kullanarak getiri tahmininde başarı şansının oldukça yüksek olduğu tespit edilmiştir.
Anahtar Kelimeler

Doğal Bootstrap Otomatik Varyans Rasyo Testi

Hisse Senedi Piyasaları

Etkin Piyasalar Hipotezi

Getiri Öngörülebilirliği

Makale Hakkında

Geliş Tarihi: 26.02.2020

Kabul Tarihi: 10.06 .2020

Doi: $10.18026 /$ cbayarsos.695125

\section{Weak-Form Market Efficiency Comparison of Stock Markets on Global Scale: An Empirical Study on G-20 Members}

\section{Abstract}

This paper analyzes stock markets of G-20 members in terms of comparing return predictability, in other words, weak-form market efficiency using stock indexes weekly data of the G-20 members between 07.06.2009 and 09.02.2020. As a result of the wild bootstrap automatic variance ratio test analysis developed by Kim (2009), it is found that the stock markets of Brazil, South Africa, and Germany were weak-form efficient in the date range within the scope of the study, so the returns are unpredictable, while the weak-form efficiency (return predictability) of other markets are time-varying. In addition to Brazil, South Africa, and Germany, there is a very low chance to estimate returns with historical price movements or returns in Russia, France, Italy, United States, United Kingdom, and Canada stock markets. It is also found that the return predictability periods of Japan, Australia, China, Saudi Arabia, and especially Mexico's stock markets are higher than other markets and the chance of success in estimating returns by using historical price information in these markets is quite high.
Keywords

Wild Bootstrap Automatic Variance Ratio Test Stock Markets

Efficient Markets Hypothesis Return Predictability

About Article

Received: 26.02.2020

Accepted: 10.06 .2020

Doi: $10.18026 /$ cbayarsos.695125

a İletişim Yazarı: oktay.ozkan@gop.edu.tr

b Arş. Gör. Dr., Tokat Gaziosmanpaşa Üniversitesi, İktisadi ve İdari Bilimler Fakültesi, İşletme Bölümü, ORCID: 0000-0001-9419-8115 


\section{Introduction}

Modern Portfolio Theory states that the investor, who diversifies his portfolio very well, will get a return approximately as much as the return provided by the market portfolio. One of the most frequently asked questions, especially as the stock markets began to develop worldwide, was whether the future price movements of the securities could be determined and the abnormal return would be obtained. As a result of the academic studies carried out to answer this question, the Efficient Markets Hypothesis developed especially by Samuelson (1965) and Fama $(1965,1970)$ has emerged, which reveals that asset prices fully and instantaneously reflect all available and relevant information (Arı and Yüksel, 2017: 78; Karan, 2013: 277).

Fama (1970) states that if the prices of securities in a market constantly reflect all available information, that market is an efficient market. In an efficient market, new information is spreading very quickly and is reflected in asset prices without delay (Malkiel, 2003: 59). The Efficient Markets Hypothesis, based on the rationality assumption, states that rational investors quickly and accurately reflect all available and new information in the market to asset prices. According to the hypothesis, since asset prices in the markets reflect all available information, it is not possible to make any profit over the market average using any information. In addition, the Efficient Markets Hypothesis emphasizes that asset prices are changing with new information coming to the markets, in other words, they occur randomly, so it is not possible to estimate future price movements by looking at past price movements of assets (Karadağlı and Omay, 2012: 235; Korkmaz et al., 2010: 1139).

According to the Efficient Markets Hypothesis, market efficiency is divided into three different forms, namely weak, semi-strong and strong, according to the information reflected by asset prices (Degutis and Novickytè, 2014: 8; Fama, 1970: 383). In the weak-form market efficiency, current securities prices reflect all historical price information (Verheyden et al., 2015: 295). Therefore, in a weak-form efficient market, future prices (returns) of assets cannot be estimated using historical price information. In semi-strong market efficiency, securities prices reflect all publicly available information (Bayraktar, 2012: 42). In strong market efficiency, securities prices reflect all information including non-public information within the company (Rossi, 2015: 286). Market efficiency forms are not independent of each other. A market efficient in a semi-strong form is also efficient in a weak-form too. Likewise, a market efficient in strong form is efficient in both weak and semi-strong form. Therefore, an inefficient market in a weak-form is neither efficient in a semi-strong form nor is it efficient in a strong form (Karan, 2013: 279).

This study focuses on return predictability, in other words, weak-form market efficiency. The main purpose of this study is to compare stock markets in terms of return predictability (weak-form market efficiency) on a global scale. This study also reveals in which markets the individual and institutional investors and portfolio managers can increase their chances of success by using historical price movements, in which markets they may have a high chance of failure. Within this framework of purpose, analysis will be carried out with the weekly data of the indexes representing the stock markets of 19 countries and the European Union members of the G-20 between 07.06.2009 and 09.02.2020 using wild bootstrap automatic variance ratio test developed by Kim (2009) to test return predictability (weak-form market efficiency), provides highly successful results in data sets that are not normally distributed and showing conditional heteroscedasticity and also provides test statistics used to 
determine the return predictability or the degree of market efficiency (inefficiency) and the findings will be interpreted.

According to the best knowledge of the author, this study is one of the first studies conducted on the G-20 members within the scope of the comparison of the return predictability, in other words, the weak-form market efficiency. With this aspect of the study, it is thought that it will make important contributions to the literature. The following sections of the study include literature review, methodology, data and empirical findings, and finally information about the result, respectively.

\section{Literature Review}

In this part of the study, there is a literature review regarding the studies carried out within the scope of the stock market of all G-20 members or some members. The literature review related to the studies carried out within the scope of the stock markets of all G-20 members is given in Table 1.

Table 1. Literature Review Related to the Studies Carried out under All G-20 Members

\begin{tabular}{|c|c|c|c|c|}
\hline Author/Authors & Year & Purpose & Methodology & Findings \\
\hline Veito et al. & 2013 & $\begin{array}{l}\text { Analyze weak-form } \\
\text { market efficiency of G- } \\
20 \text { countries before and } \\
\text { during the } 2007 \text { crisis }\end{array}$ & $\begin{array}{l}\text { Serial correlation, } \\
\text { RWH, ADF, ranks } \\
\text { and signs based } \\
\text { multiple variance } \\
\text { ratio, and variance } \\
\text { ratio test }\end{array}$ & $\begin{array}{l}\text { The markets of most G- } \\
20 \text { countries is weak- } \\
\text { form efficient }\end{array}$ \\
\hline $\begin{array}{l}\text { Gümüş and } \\
\text { Zeren }\end{array}$ & 2014 & $\begin{array}{l}\text { Analyze the weak-form } \\
\text { stock markets efficiency } \\
\text { of G-20 countries except } \\
\text { for the European Union, } \\
\text { South Africa, and Saudi } \\
\text { Arabia }\end{array}$ & Unit root tests & $\begin{array}{l}\text { Turkey, } \\
\text { Indonesia, } \\
\text { Canada, Mexico, } \\
\text { Russia, South } \\
\text { and Korea, } \\
\text { markets are not } \\
\text { form efficient }\end{array}$ \\
\hline $\begin{array}{l}\text { Özcan and } \\
\text { Gültekin }\end{array}$ & 2016 & $\begin{array}{l}\text { Examine the weak-form } \\
\text { market efficiency of G- } \\
20 \text { countries except for } \\
\text { the European Union } \\
\text { and Saudi Arabia }\end{array}$ & Panel Stability test & $\begin{array}{l}\text { Stock exchange markets } \\
\text { of G-20 countries } \\
\text { except for Argentina, } \\
\text { Canada, China, and } \\
\text { Russia are weak-form } \\
\text { efficient }\end{array}$ \\
\hline $\begin{array}{l}\text { Kayral and } \\
\text { Alagoz }\end{array}$ & 2019 & $\begin{array}{l}\text { Investigate the weak- } \\
\text { form stock exchanges } \\
\text { efficiency of G-20 } \\
\text { countries }\end{array}$ & $\begin{array}{l}\text { Variance analysis } \\
\text { and unit root tests }\end{array}$ & $\begin{array}{l}\text { Stock exchanges of G- } \\
20 \text { countries except for } \\
\text { US, India, Saudi } \\
\text { Arabia, and China are } \\
\text { weak-form efficient }\end{array}$ \\
\hline
\end{tabular}

No other study of return predictability or weak-form market efficiency for all G-20 members has been found in the literature. The literature review related to the studies carried out within the scope of the stock markets of some members of G-20 is given in Table 2. 
Table 2. Literature Review Related to the Studies Carried out under Some G-20 Members

\begin{tabular}{|c|c|c|c|c|}
\hline Author/Authors & Year & Purpose & Methodology & Findings \\
\hline Choudhry & 1994 & $\begin{array}{l}\text { Analyze the weak-form } \\
\text { efficiency of Canada, } \\
\text { France, Germany, Japan } \\
\text { and Italy stock indexes }\end{array}$ & $\begin{array}{l}\text { ADF, KPSS, and } \\
\text { Johansen } \\
\text { cointegration } \\
\text { tests }\end{array}$ & $\begin{array}{l}\text { All stock indexes within } \\
\text { the scope of the study are } \\
\text { weak-form efficient }\end{array}$ \\
\hline $\begin{array}{l}\text { Vaidyanathan } \\
\text { and Gali }\end{array}$ & 1994 & $\begin{array}{l}\text { Examine the weak-form } \\
\text { market efficiency of India }\end{array}$ & $\begin{array}{l}\text { Runs tests and } \\
\text { serial correlation } \\
\text { analysis }\end{array}$ & Weak-form efficient \\
\hline Urrutia & 1995 & $\begin{array}{l}\text { Analyze the weak-form } \\
\text { stock markets efficiency of } \\
\text { Argentina, Brazil, Chile, } \\
\text { and Mexico }\end{array}$ & $\begin{array}{l}\text { Variance ratio } \\
\text { analysis }\end{array}$ & Weak-form efficient \\
\hline Chan et al. & 1998 & $\begin{array}{l}\text { Investigate the weak-form } \\
\text { stock markets efficiency of } \\
18 \text { countries }\end{array}$ & Unit root tests & $\begin{array}{l}\text { All international stock } \\
\text { markets within the scope } \\
\text { of the study are weak- } \\
\text { form efficient }\end{array}$ \\
\hline $\begin{array}{l}\text { Dahel and } \\
\text { Laabas }\end{array}$ & 1999 & $\begin{array}{l}\text { Analyze the weak-form } \\
\text { stock markets efficiency of } \\
\text { the Bahrain, Kuwait, } \\
\text { Saudi Arabia, and Oman }\end{array}$ & Unit root tests & $\begin{array}{l}\text { Only stock market of } \\
\text { Kuwait is weak-form } \\
\text { efficient }\end{array}$ \\
\hline Yinggang & 2001 & $\begin{array}{l}\text { Analyze the weak-form } \\
\text { stock market efficiency of } \\
\text { the China }\end{array}$ & $\begin{array}{l}\text { Generalized } \\
\text { spectral analysis }\end{array}$ & Not weak-form efficient \\
\hline $\begin{array}{l}\text { Abrosimova et } \\
\text { al. }\end{array}$ & 2002 & $\begin{array}{l}\text { Examine the weak-form } \\
\text { stock exchange efficiency } \\
\text { of Russia }\end{array}$ & Unit root tests & Weak-form efficient \\
\hline $\begin{array}{l}\text { Worthington } \\
\text { and Higgs }\end{array}$ & 2003 & $\begin{array}{l}\text { Analyze the weak-form } \\
\text { stock markets efficiency of } \\
\text { Argentina, Brazil, Chile, } \\
\text { Colombia, Mexico, Peru, } \\
\text { and Venezuela }\end{array}$ & $\begin{array}{l}\text { Serial correlation } \\
\text { runs, unit root, } \\
\text { and multiple } \\
\text { variance ratio } \\
\text { tests. }\end{array}$ & $\begin{array}{l}\text { All stock markets within } \\
\text { the scope of the study are } \\
\text { not weak-form efficient }\end{array}$ \\
\hline Gupta and Basu & 2007 & $\begin{array}{l}\text { Investigate the weak-form } \\
\text { efficiency of two major } \\
\text { equity markets in India }\end{array}$ & Unit root tests & Not weak-form efficient \\
\hline $\begin{array}{l}\text { Narayan and } \\
\text { Smyth }\end{array}$ & 2007 & $\begin{array}{l}\text { Examine the weak-form } \\
\text { stock markets efficiency of } \\
\text { the G-7 countries }\end{array}$ & $\begin{array}{l}\text { Two-break LM } \\
\text { unit root test }\end{array}$ & $\begin{array}{l}\text { All stock markets within } \\
\text { the scope of the study are } \\
\text { weak-form efficient }\end{array}$ \\
\hline Narayan & 2008 & $\begin{array}{l}\text { Examine the weak-form } \\
\text { stock markets efficiency of } \\
\text { the G-7 countries }\end{array}$ & $\begin{array}{l}\text { Panel LM unit } \\
\text { root test }\end{array}$ & $\begin{array}{l}\text { All stock markets within } \\
\text { the scope of the study are } \\
\text { not weak-form efficient }\end{array}$ \\
\hline Qian et al. & 2008 & $\begin{array}{l}\text { Analyze the weak-form } \\
\text { stock market efficiency of } \\
\text { the China }\end{array}$ & $\begin{array}{l}\text { Threshold unit } \\
\text { root test }\end{array}$ & Weak-form efficient \\
\hline Ergül & 2009 & $\begin{array}{l}\text { Examine weak-form stock } \\
\text { market efficiency of } \\
\text { Turkey }\end{array}$ & Unit root tests & Weak-form efficient \\
\hline Suresh et al. & 2013 & $\begin{array}{l}\text { Analyze the weak-form } \\
\text { stock markets efficiency of } \\
\text { the BRICS members }\end{array}$ & $\begin{array}{l}\text { Panel unit root } \\
\text { tests }\end{array}$ & Not weak-form efficient \\
\hline
\end{tabular}




\begin{tabular}{|c|c|c|c|c|}
\hline $\begin{array}{l}\text { Said and } \\
\text { Harper }\end{array}$ & 2015 & $\begin{array}{l}\text { Examine the weak-form } \\
\text { stock market efficiency of } \\
\text { Russia }\end{array}$ & $\begin{array}{l}\text { Box-Ljung and } \\
\text { the variance ratio } \\
\text { tests }\end{array}$ & Not weak-form efficient \\
\hline $\begin{array}{l}\text { Malcioglu and } \\
\text { Aydin }\end{array}$ & 2016 & $\begin{array}{l}\text { Investigate weak-form } \\
\text { stock market efficiency of } \\
\text { Turkey }\end{array}$ & $\begin{array}{l}\text { Harvey linearity } \\
\text { test }\end{array}$ & Not weak-form efficient \\
\hline Hamid et al. & 2017 & $\begin{array}{l}\text { Examine the weak-form } \\
\text { efficiency of } 14 \text { countries } \\
\text { stock markets }\end{array}$ & $\begin{array}{l}\text { Autocorrelation, } \\
\text { Ljung box, runs, } \\
\text { unit root, and the } \\
\text { variance ratio } \\
\text { tests }\end{array}$ & $\begin{array}{l}\text { All stock markets within } \\
\text { the scope of the study are } \\
\text { not weak-form efficient }\end{array}$ \\
\hline Kiran et al. & 2019 & $\begin{array}{l}\text { Analyze the weak-form } \\
\text { stock markets efficiency of } \\
\text { the BRICS members }\end{array}$ & $\begin{array}{l}\text { Serial correlation, } \\
\text { Ljung box, and } \\
\text { runs tests }\end{array}$ & Weak-form efficient \\
\hline
\end{tabular}

\section{Methodology}

In this study, wild bootstrap automatic variance ratio test developed by Kim (2009) was applied for predictability of returns (or weak-form market efficiency). Lo and MacKinlay's (1988) variance ratio test is a method frequently used in the finance literature to evaluate the return predictability of assets. However, the method reveals unsuccessful results in small samples due to insufficient properties, particularly under conditional heteroscedasticity typical features of financial data. In addition, since it requires ad hoc choices for lag length or holding period, this also weakens its small sample properties. Kim (2006) developed the wild bootstrap variance ratio test and tried to improve its small sample properties, especially under conditional heteroscedasticity. To overcome the problem of choosing lag length or holding period with an ad hoc way, Kim (2009) developed the wild bootstrap automatic variance ratio (WBAVR) test, where the optimal holding period is automatically chosen with the fully data-dependent procedure. Charles et al. (2011) in their study with Monte Carlo test, stated that the WBAVR test showed quite sufficient small sample (size and power) properties and was more successful than other variance ratio tests for return predictability (or weak-form market efficiency). This part of the study presents brief details about the WBAVR test.

The statistical form of the original variance ratio test is shown in equation 1.

$$
\widehat{V R}(k)=1+2 \sum_{i=1}^{k-1}\left(1-\frac{i}{k}\right) \hat{p}(i)
$$

The $\mathrm{k}$ in the Eq. (1) refers to the holding period. Under the null hypothesis of MDS (no return predictability), a standardized version of Eq. (1) asymptotically follows the standard normal distribution (Lo and MacKinlay, 1988). Choi (1999) proposed the automatic variance ratio (AVR) test where holding period is chosen optimally using a fully data-dependent method of Andrews (1991) as the original variance ratio test requires an ad hoc choice of holding period. Kim (2009) developed the WBAVR test with the wild bootstrap of Mammen (1993) to overcome the deficiency of Choi's (1999) AVR test in data showing conditional heteroscedasticity. The WBAVR test is performed in the following three steps:

1. Form a bootstrap sample of size $T$ as $Y_{t}^{*}=\eta_{t} Y_{t}(t=1, \ldots, T)$,

2. Calculate $A V R^{*}\left(k^{*}\right)$, 
3. Repeat 1 and 2 choosen bootstrap replications (B) times, to produce the bootstrap distribution of the AVR statistic $\left\{A V R^{*}\left(k^{*} ; j\right)\right\}_{j=1}^{B}$.

If the $\mathrm{p}$ value obtained as a result of the WBAVT test is lower than the value determined as the level of significance (in this study 0.10), the null hypothesis of MDS (no return predictability) is rejected at the value determined as the level of significance. In this study, the number of bootstrap replications B is set at 500 as in Charles et al. (2015).

\section{Data and Empirical Results}

In this study, weekly data of the indexes representing the stock market of 19 countries (Argentina (ARG), Australia (AUS), Brazil (BRA), Canada (CAN), China (CHN), Germany (DEU), France (FRA), India (IND), Indonesia (IDN), Italy (ITA), Japan (JPN), Mexico (MEX), Russia (RUS), Saudi Arabia (SAU), South Africa (ZAF), South Korea (KR), Turkey (TUR), the United Kingdom (UK) and the United States (USA)) and the European Union (EU) members of the G-20 between 07.06.2009 and 09.02.2020 were used. The data of the indexes were obtained from Investing (Date of Access: 10.02.2020). Weekly returns are calculated by taking the natural logarithmic first differences of the data obtained as weekly closing prices. Also, logarithmic returns are multiplied by 100 to avoid the convergence problem. Table 3 shows the descriptive statistics regarding the logarithmic weekly returns of the stock indexes within the scope of the study.

Table 3. Descriptive Statistics

\begin{tabular}{ccccccc}
\hline Data & Mean & S.D. & Skewness & Kurtosis & JB & ARCH \\
\hline DEU & 0.176 & 2.598 & -0.487 & 5.022 & $116.936^{* * *}$ & $59.975^{* * *}$ \\
USA & 0.226 & 1.963 & -0.488 & 4.836 & $100.385^{* * *}$ & $67.725^{* * *}$ \\
ARG & 0.576 & 4.796 & -1.098 & 10.285 & $1343.737^{* * * *}$ & $17.949^{*}$ \\
AUS & 0.098 & 1.901 & -0.471 & 4.475 & $71.145^{* * *}$ & $41.585^{* * *}$ \\
BRA & 0.133 & 2.899 & 0.087 & 4.712 & $68.726^{* * *}$ & 12.113 \\
CHN & 0.009 & 2.931 & -0.586 & 5.638 & $193.356^{* * *}$ & $110.576^{* * *}$ \\
IDN & 0.188 & 2.166 & -0.622 & 6.316 & $291.078^{* * *}$ & $37.046^{* * *}$ \\
FRA & 0.106 & 2.559 & -0.4512 & 4.620 & $79.825^{* * *}$ & $57.773^{* * *}$ \\
ZAF & 0.162 & 2.093 & -0.071 & 3.365 & 3.554 & $22.281^{* * *}$ \\
KR & 0.078 & 2.027 & -0.694 & 5.197 & $156.748^{* * *}$ & $58.236^{* * *}$ \\
IND & 0.173 & 2.209 & -0.144 & 4.098 & $29.893^{* * *}$ & $43.456^{* * *}$ \\
JPN & 0.152 & 2.676 & -0.423 & 4.450 & $65.476^{* * *}$ & 15.963 \\
CAN & 0.092 & 1.711 & -0.531 & 4.533 & $80.756^{* * *}$ & $75.210^{* * * *}$ \\
MEX & 0.099 & 2.068 & -0.016 & 4.072 & $26.704^{* * *}$ & $42.347^{* * *}$ \\
RUS & 0.052 & 3.906 & -0.368 & 5.088 & $113.743^{* * *}$ & $54.328^{* * *}$ \\
SAU & 0.053 & 2.435 & -0.676 & 9.354 & $979.363^{* * * *}$ & $77.286^{* * *}$ \\
TUR & 0.220 & 3.161 & -0.550 & 4.266 & $65.340^{* * *}$ & 12.169 \\
ITA & 0.033 & 3.071 & -0.494 & 4.179 & $54.922^{* * *}$ & $49.040^{* * *}$ \\
UK & 0.093 & 1.988 & -0.424 & 5.250 & $134.171^{* * *}$ & $27.325^{* * *}$ \\
EU & 0.074 & 2.608 & -0.413 & 4.579 & $73.713^{* * * *}$ & $55.037^{* * *}$ \\
\hline
\end{tabular}

Note: The null hypothesis of the JB test is based on the assumption that the relevant data is normally distributed. ${ }^{* * *},{ }^{* * *},{ }^{*}$ indicate $1 \%, 5 \%$ and $10 \%$ significance level, respectively. S.D., JB, and ARCH represent standard deviation, Jarque-Bera, and Autoregressive Conditional Heteroscedasticity, respectively. 
Looking at Table 3, it is seen that Argentina's stock market index has the highest average return and volatility. Skewness values indicate that index returns except for Brazil's index return skewed to the right are skewed to the left. Kurtosis values show that the distributions of index returns except for South Africa's index return are leptokurtic (pointed and fattailed). The JB test for normality results also indicates that the null hypothesis will be rejected at $1 \%$ significance level, in other words, the return series except for South Africa are not normally distributed. Finally, the ARCH-LM test results developed by Engle (1982), which shows the conditional heteroscedasticity states of the data sets, shows that all data sets except for Brazil, Japan, and Turkey's data sets have conditional heteroscedasticity at $1 \%$ significance level. The vast majority of the data used in the study are not normally distributed and show conditional heteroscedasticity features. As mentioned earlier, the WBAVR test by which the analyzes will be conducted performs well against these features. Since the WBAVR test requires the data to be analyzed to be stationary, the stationarity states of the return series were examined with the Phillips-Perron (PP) unit root test developed by Phillips and Perron (1988). PP unit root test results are given in Table 4.

Table 4. PP Unit Root Test Results

\begin{tabular}{|c|c|c|c|c|}
\hline \multirow{2}{*}{ Data } & \multicolumn{2}{|c|}{ Intercept } & \multicolumn{2}{|c|}{ Trend and Intercept } \\
\hline & t-Statistic & Probability & $\mathrm{t}$-Statistic & Probability \\
\hline DEU & -25.088 & $0.000^{* * *}$ & -25.084 & $0.000^{* * * *}$ \\
\hline USA & -26.912 & $0.000^{* * * *}$ & -26.904 & $0.000^{* * *}$ \\
\hline ARG & -23.470 & $0.000^{* * * *}$ & -23.448 & $0.000^{* * *}$ \\
\hline AUS & -26.662 & $0.000^{* * * *}$ & -26.636 & $0.000^{* * *}$ \\
\hline BRA & -24.310 & $0.000^{* * * *}$ & -24.336 & $0.000^{* * *}$ \\
\hline $\mathrm{CHN}$ & -22.142 & $0.000^{* * *}$ & -22.123 & $0.000^{* * * *}$ \\
\hline IDN & -27.129 & $0.000^{* * * *}$ & -27.374 & $0.000^{* * *}$ \\
\hline FRA & -25.499 & $0.000^{* * * *}$ & -25.475 & $0.000^{* * *}$ \\
\hline ZAF & -25.941 & $0.000^{* * * *}$ & -26.930 & $0.000^{* * *}$ \\
\hline KR & -25.038 & $0.000^{* * * *}$ & -25.133 & $0.000^{* * *}$ \\
\hline IND & -24.811 & $0.000^{* * *}$ & -24.785 & $0.000^{* * * *}$ \\
\hline JPN & -23.360 & $0.000^{* * * *}$ & -23.338 & $0.000^{* * *}$ \\
\hline CAN & -25.870 & $0.000^{* * * *}$ & -25.849 & $0.000^{* * * *}$ \\
\hline MEX & -26.364 & $0.000^{* * * *}$ & -26.616 & $0.000^{* * *}$ \\
\hline RUS & -24.022 & $0.000^{* * * *}$ & -23.999 & $0.000^{* * *}$ \\
\hline SAU & -22.545 & $0.000^{* * * *}$ & -22.530 & $0.000^{* * *}$ \\
\hline TUR & -25.296 & $0.000^{* * * *}$ & -25.297 & $0.000^{* * *}$ \\
\hline ITA & -24.017 & $0.000^{* * *}$ & -24.007 & $0.000^{* * * *}$ \\
\hline UK & -25.549 & $0.000^{* * *}$ & -25.668 & $0.000^{* * * *}$ \\
\hline EU & -25.548 & $0.000^{* * *}$ & -25.524 & $0.000^{* * * *}$ \\
\hline
\end{tabular}

Note: The null hypothesis indicates that the data has a unit root, in other words, the data is not stationary and ${ }^{* * * * * *},{ }^{*}$ indicates $1 \%, 5 \%$, and $10 \%$ significance level, respectively.

When the stationary outputs in Table 4 are analyzed, it is understood that the null hypothesis is rejected at $1 \%$ significance level for all return series, in other words, all data sets are stationary. These results indicate that analysis can be carried out with the returns of the indexes used in the study. In order to compare the stock markets of G-20 members in terms of return predictability (weak-form market efficiency), this study used 2-year subsamples consisting of approximately 104 weeks of observation. It was stated in the study 
conducted by Charles et al. (2011) that the data size determined within the scope of this study is ideal. Also, the 2-year sub-sample size is suitable for capturing the effects of changing market conditions (Charles et al., 2015: 15). The first sub-sample covers weekly returns between 14.06.2009 and 05.06.2011. After the analysis was applied to the first subsample window, the new sub-sample window was created by rolling the window 1 week forward. With this method, a total of 454 sub-sample windows were created and $p$ values were calculated as a result of the analysis performed for each sub-sample window. The graphs of the $p$ values obtained for each return series as a result of the analysis are given in Figure 1.

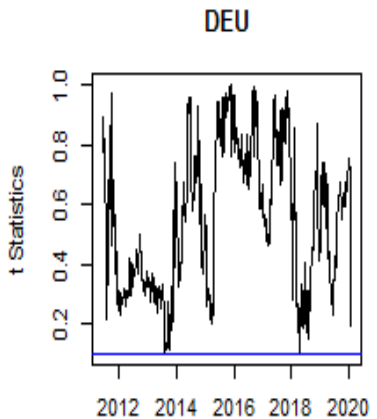

Date

BRA

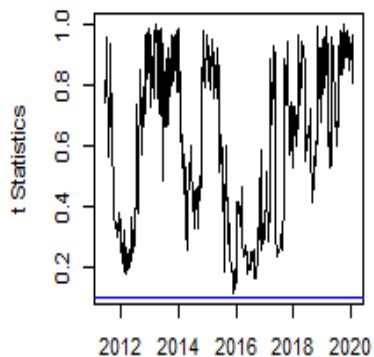

Date

ZAF

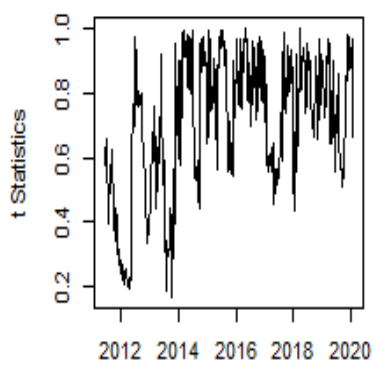

Date
USA

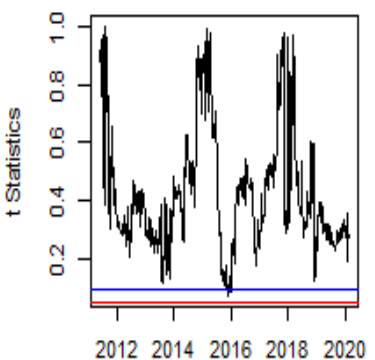

Date

CHN

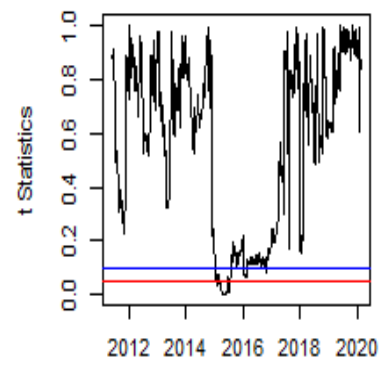

Date

KR

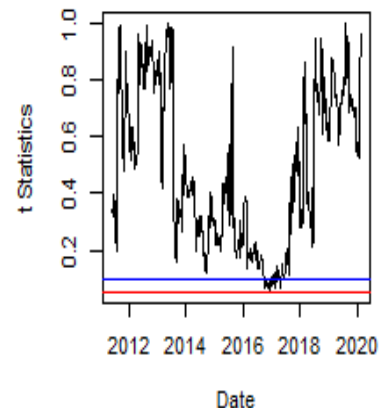

ARG

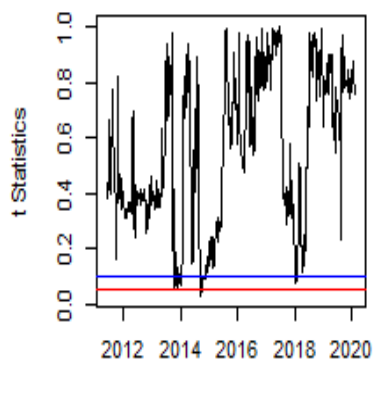

Date

IDN

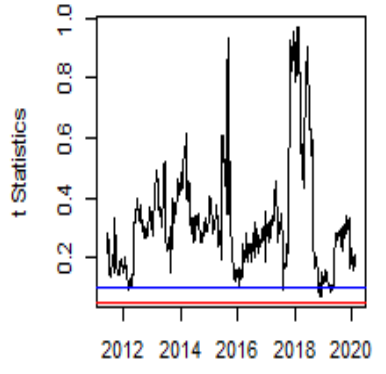

Date

IND

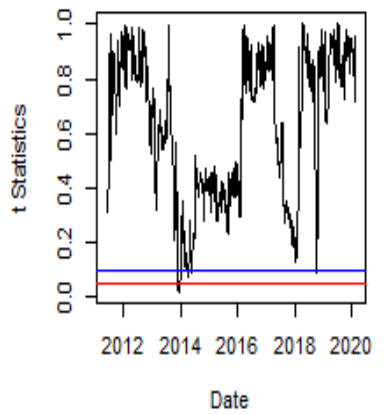

AUS

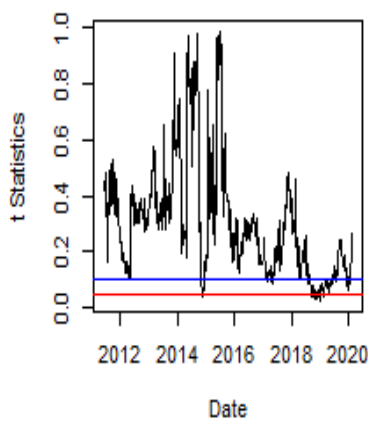

FRA

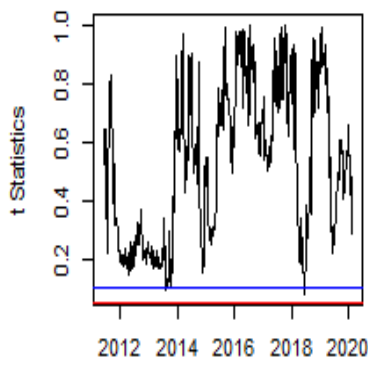

Date

JPN

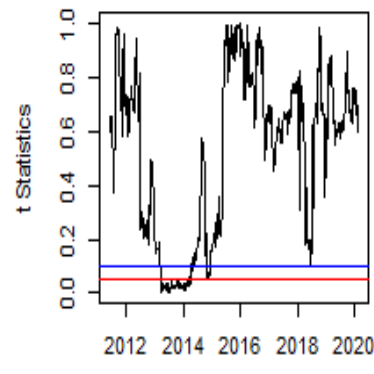

Date 


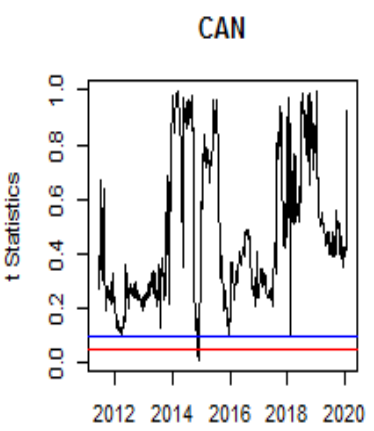

Date

TUR

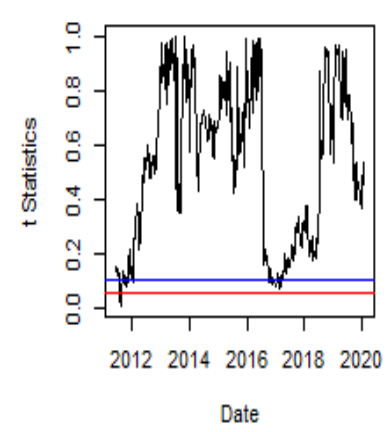

MEX

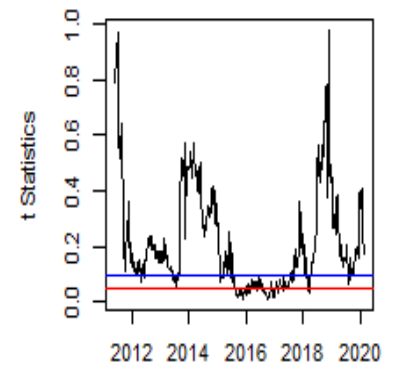

Date

ITA

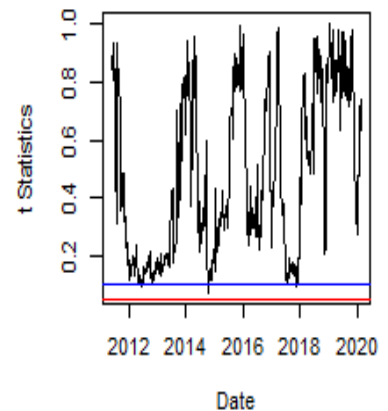

RUS

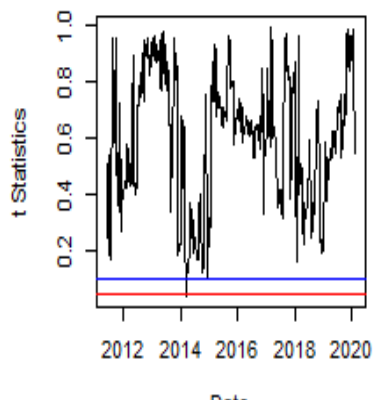

Date

UK

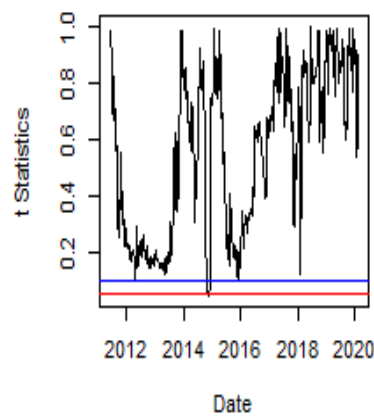

SAU

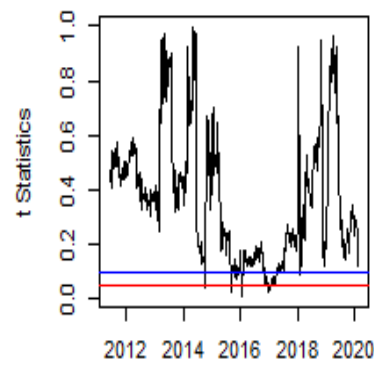

Date

EU

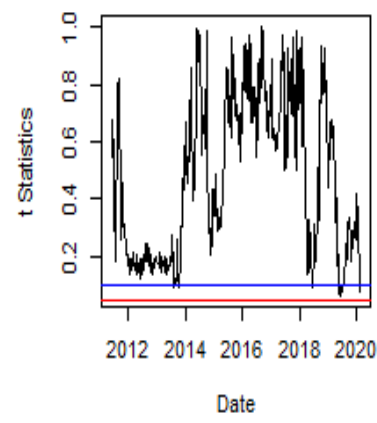

Figure 1. WBAVR Test Outputs

Note: The null hypothesis states that returns are unpredictable. The horizontal line indicates $5 \%$ and $10 \%$ significance levels.

The horizontal line in the graphs showing the WBAVR test results in Figure 1 shows the 5\% and $10 \%$ significance levels. The fact that the $\mathrm{p}$ value obtained for each sub-sample window is smaller than the significance levels indicates that the null hypothesis will be rejected in the relevant period, in other words, the returns are predictable in that period. The $p$ values, which are greater than the significance levels, indicate that the null hypothesis will be accepted, so the returns cannot be predicted. When the graphs in Figure 1 are analyzed, it is seen that the returns are predictable in certain periods in the stock markets except for Brazil, South Africa, and Germany's stock markets, and the returns are unpredictable in certain periods. Table 5 shows the number of weeks in which the return series within the scope of the study are predictable.

Table 5. Number of Weeks in Which Returns Are Predictable

\begin{tabular}{|c|c|c|c|c|c|c|c|}
\hline \multicolumn{2}{|c|}{ BRA } & \multicolumn{2}{|c|}{ ZAF } & \multicolumn{2}{|c|}{ DEU } & \multicolumn{2}{|c|}{ RUS } \\
\hline 0 & 0 & 0 & 0 & 0 & 0 & 1 & 1 \\
\hline \multicolumn{2}{|c|}{ FRA } & \multicolumn{2}{|c|}{ ITA } & \multicolumn{2}{|c|}{ USA } & \multicolumn{2}{|c|}{ UK } \\
\hline 2 & 0 & 3 & 0 & 4 & 0 & 5 & 1 \\
\hline \multicolumn{2}{|c|}{ CAN } & \multicolumn{2}{|c|}{ IDN } & \multicolumn{2}{|c|}{ EU } & \multicolumn{2}{|c|}{ IND } \\
\hline 5 & 4 & 10 & 0 & 14 & 0 & 13 & 5 \\
\hline \multicolumn{2}{|c|}{ KR } & \multicolumn{2}{|c|}{ ARG } & \multicolumn{2}{|c|}{ TUR } & \multicolumn{2}{|c|}{ SAU } \\
\hline 22 & 0 & 22 & 1 & 23 & 2 & 39 & 8 \\
\hline \multicolumn{2}{|c|}{ CHN } & \multicolumn{2}{|c|}{ AUS } & \multicolumn{2}{|c|}{ JPN } & \multicolumn{2}{|c|}{ MEX } \\
\hline 41 & 21 & 55 & 13 & 62 & 54 & 148 & 53 \\
\hline
\end{tabular}


The numbers on the left in Table 5 show the number of weeks in which returns are predictable with a $10 \%$ significance level, while the numbers on the right show the number of weeks in which returns are predictable with a $5 \%$ significance level. When Table 5 is analyzed, it is understood that there is no return predictability period in the date range within the scope of the study in Brazil, South Africa, and Germany's stock markets. The stock markets of these countries are weak-form efficient while the weak-form efficiency (return predictability) of other markets varied periodically, therefore, individual and institutional investors and portfolio managers can not obtain abnormal returns by using historical data in the stock markets of these countries. In addition to these three countries, the chance of forecasting the returns of stocks is very low by using historical price movements or returns in Russia, France, Italy, United States, United Kingdom, and Canada country's stock markets. Looking at Table 5 again, it is understood that the Mexican stock market has by far the most period in which returns are predictable. Using the historical price movements or returns of stocks in the Mexican financial markets, the chance of obtaining abnormal returns is quite high. Besides Mexico, there is a high chance of obtaining abnormal returns by using historical price movements or returns in Japan, Australia, China, and Saudi Arabia stock markets which have less weak-form efficiency periods compared to other countries. The stocks of these countries are ideal for individual and institutional investors and portfolio managers who have an investment strategy on historical price movements.

\section{Conclusion}

In this study carried out to compare stock markets in terms of return predictability, in other words, weak-form market efficiency on a global scale, the weekly return data of the indexes representing the stock markets of 19 countries and the European Union members of the G-20 between 07.06.2009 and 09.02.2020 were used. Within this framework, analysis were carried out using wild bootstrap automatic variance ratio test developed by Kim (2009) to test weakform market efficiency or return predictability, provides highly successful results in data sets that are not normally distributed and showing conditional heteroscedasticity and also provides test statistics used to determine the return predictability or the degree of market efficiency (inefficiency). As a result of the analysis, it is determined that the returns in Brazil, South Africa, and Germany stock markets are unpredictable in the date range within the scope of the study, in other words, these markets are efficient in weak-form, while the weakform efficiency of other countries' stock markets changes time to time. For this reason, historical price movements or returns cannot be used in the stock markets of these countries for the estimation of returns. In addition to Brazil, South Africa, and Germany, there is a very low chance to estimate returns with historical price movements or returns in Russia, France, Italy, United States, United Kingdom, and Canada stock markets. After the analysis, it is also seen that the stock market, which has the highest return predictability period, belongs to the Mexican country. Besides Mexico, stock markets belonging to Japan, Australia, China, and Saudi Arabia also have high predictable periods compared to other stock markets. Successful results about the estimation of returns can be achieved by using historical price movements or returns in Mexico, Japan, Australia, China, and Saudi Arabia stock markets, which have less weak-form efficiency periods compared to other countries. My advice to individual and institutional investors and portfolio managers with an investment strategy based on historical price movements or returns to increase their chances of success is work on Mexico, Japan, Australia, China, and Saudi Arabia stock markets rather than Brazil, South Africa, Germany, Russia, France, Italy, United States, United Kingdom, and Canada. 


\section{References}

Abrosimova, N., Dissanaike, G., \& Linowski, D. (2002). Testing the weak- form efficiency of the Russian stock market. SSRN Working Paper, European Finance Association Conference. DOI: 10.2139/ssrn.302287

Arı, A., \& Yüksel, Ö. (2017). BİST 100'de haftanın günü anomalisi: Ekonometrik bir analiz. Finans Politik $\mathcal{E}$ Ekonomik Yorumlar, 54(632), 77-89.

Bayraktar, A. (2012). Etkin Piyasalar Hipotezi. Aksaray Üniversitesi İktisadi ve İdari Bilimler Fakültesi Dergisi, 4(1), 3747.

Chan, K. C., Gup, B. E., \& Pan, M. S. (1997). International stock market efficiency and integration: A study of eighteen nations. Journal of Business Finance $\mathcal{E}$ Accounting, 24(6), 803-813. DOI: 10.1111/1468-5957.00134

Charles, A., Darné, O., \& Kim, J. H. (2011). Small sample properties of alternative tests for martingale difference hypothesis. Economics Letters, 110, 151-154. DOI: 10.1016/j.econlet.2010.11.018

Charles, A., Darné, O., \& Kim, J. H. (2015), Adaptive Markets Hypothesis for Islamic Stock Portfolios: Evidence from Dow Jones Size and Sector-indices. SSRN Working Paper. DOI: 10.2139/ssrn.2611472

Charles, A., Darné, O., \& Kim, J. H. (2015). Will precious metals shine? A market efficiency perspective. International Review of Financial Analysis, 41, 284-291. DOI: 10.1016/j.irfa.2015.01.018

Choudhry, T. 1994. Stochastic trends and stock prices: An international inquiry. Applied Financial Economics, 4(6), 383-390. DOI: 10.1080/758518670

Dahel, R., \& Laabas, B. (1999). The behavior of stock prices in the GCC markets. Journal of Development E Economic Policies, 1, 89-105.

Degutis, A., \& Novickytè, L. (2014). The efficient market hypothesis: A critical review of literature and methodology. Ekonomika, 93(2), 7-23.

Engle, R. F. (1982). Autoregressive conditional heteroscedasticity with estimates of the variance of United Kingdom inflations. Econometrica, 50(4), 987-1007. DOI: 10.2307/1912773

Ergül, N. (2009). Ulusal Hisse Senetleri Piyasası'nda etkinlik. Yönetim Bilimleri Dergisi, 7(1), 101-117.

Fama, E. F. (1965). The behaviour of stock market prices. Journal of Business, 38, 34-105.

Fama, E. F. (1970). Efficient capital markets: A review of theory and empirical work. Journal of Finance, 25, 383-417. DOI: $10.2307 / 2325486$

Gupta, R., \& Basu, P. K. (2007). Weak-form efficiency in Indian stock markets. International Business E Economics Research Journal, 6(3), 57-64. DOI: 10.19030/iber.v6i3.3353

Gümüş, F. B., \& Zeren, F. (2014). Analyzing The Efficient Market Hypothesis with the Fourier unit root tests: Evidence from G-20 countries. Ekonomski Horizonti, 16(3), 225-237. DOI: 10.5937/ekonhor1403225g

Hamid, K., Suleman, M. T., Shah, S. Z. A., \& Akash, R. S. I. (2017). Testing the weak-form of Efficient Market Hypothesis: Empirical evidence from Asia-Pacific markets. SSRN Working Paper. DOI: 10.2139/ssrn.2912908

Investing, https://tr.investing.com, [Date of Access: 10.02.2020].

Karadağlı, E. C., \& Omay, N. C. (2012). Testing weak-form market efficiency of Emerging markets: A nonlinear approach. Journal of Applied Economic Sciences, 7(3), 235-245.

Karan, M. B. (2013). Yatırım analizi ve portföy yönetimi. Ankara: Gazi Kitabevi.

Kayral, İ. E., \& Alagöz, H. M. (2019). G-20 üyesi ülke borsalarının zayıf formda piyasa etkinliğinin test edilmesi. Muhasebe Bilim Dünyası Dergisi, 21(3), 809-828. DOI: 10.31460/mbdd.531351

Kim, J. H. (2006). Wild bootstrapping variance ratio tests. Economics Letters, 92, 38-43. DOI: 10.1016/j.econlet.2006.01.007

Kim, J. H. (2009). Automatic variance ratio test under conditional heteroskedasticity. Finance Research Letters, 3, 179-185. DOI: 10.1016/j.frl.2009.04.003

Kiran, M. S. S., Mallikarjunaand, M., \& Rao, R. P. (2019). Testing the weak-form efficiency of BRICS stock markets. Asian Journal of Economics, Finance and Management, 1(3), 115-123. 
Korkmaz, T., Başaran, Ü., \& Çevik, E. İ. (2010). Yaz saati uygulaması anomalisinin İMKB 100 endeks getirisine etkisinin test edilmesi. Ege Akademik Bakış, 10(4), 1139-1153.

Lo, A. W., \& MacKinlay, A. C. (1988). Stock market prices do not follow random walk: Evidence from a simple specification test. The Review of Financial Studies, 1, 41-66. DOI: 10.1093/rfs/1.1.41

Malcığlu, G., \& Aydın, M. (2016). Borsa İstanbul'da piyasa etkinliğinin analizi: Harvey doğrusallık testi. Journal of Accounting, Finance and Auditing Studies, 2(1), 112-123.

Malkiel, B. G. (2003). The Efficient Market Hypothesis and its critics. Journal of Economic Perspectives, 17(1), 59-82. DOI: $10.1257 / 089533003321164958$

Mammen, E. (1993). Bootstrap and wild bootstrap for high dimensional linear models. The Annals of Statistics, 21, 255-285.

Narayan, P. K. (2008). Do shocks to G7 stock prices have a permanent effect? Mathematics and Computers in Simulation, 77(4), 369-373. DOI: 10.1016/j.matcom.2007.03.003

Narayan, P. K., \& Smyth, R. (2007). Mean reversion versus random walk in G7 stock prices evidence from multiple trend break unit root tests. Journal of International Financial Markets, Institutions and Money, 17, 152166. DOI: 10.1016/j.intfin.2005.10.002

Özcan, B., \& Gültekin, E. (2016). Etkin Piyasalar Hipotezi G-20 ülkeleri için geçerli mi? Yeni bir yaklaşım. ICEB Konferans Bildirileri, 12-17.

Phillips, P. C. B. \& Perron, P. (1988). Testing for a unit root in time series regression. Biometrika, 75(2), 335-346. DOI: 10.1093/biomet/75.2.335

Qian, X. Y., Song, F. T., \& Zhou, W. X. (2008). Nonlinear behaviour of the Chinese SSEC index with a unit root: evidence from threshold unit root tests. Physica A: Statistical Mechanics and Its Applications, 387, 503-510. DOI: 10.1016/j.physa.2007.09.029

Rossi, M. (2015). The Efficient Market Hypothesis and calendar anomalies: A literature review. International Journal of Managerial and Financial Accounting, 7(3/4), 285-296. DOI: 10.1504/IJMFA.2015.074905

Said, A., \& Harper, A. (2015). The efficiency of the Russian stock market: A revisit of the Random Walk Hypothesis. Academy of Accounting and Financial Studies Journal, 19(1), 42-48.

Samuelson, P. A. (1965). Proof that properly anticipated prices fluctuate randomly. Industrial Management Review, $6,41-9$.

Suresh K. G., Joseph, A., \& Sisodia, G. (2013). Efficiency of emerging stock markets: Evidences from "BRICS" stock indices data using nonlinear panel unit root test. Journal of Economic and Financial Modelling, 1(1), 56-61.

Urrutia, J. (1995). Tests of random walk and market efficiency for Latin American Emerging Markets. Journal of Financial Research, 18(3), 299-309. DOI: 10.1111/j.1475-6803.1995.tb00568.x

Vaidyanathan, R., \& Gali, K. K. (1994). Efficiency of the Indian capital market. Indian Journal of Finance and Research, 5(2), 35-38

Verheyden, T., Moor, L. D., \& Bossche, F. V. D. (2015). Towards a new framework on efficient markets. Research in International Business and Finance, 34, 294-308. DOI: 10.1016/j.ribaf.2015.02.007

Vieito, J. P., Murthy, K. V. B., \& Tripathi, V. (2013). Market efficiency in G-20 countries: The paradox of financial crisis. Annals of Financial Economics, 8(1), 1-27. DOI: 10.1142/S2010495213500036

Worthington, A. C., \& Higgs, H., (2003). Tests of random walks and market efficiency in Latin American stock markets: An empirical note. School of Economics and Finance Discussion Papers and Working Papers Series, No, 157.

Yinggang, Z. Y. Z. (2001). Are China's Stock Markets Weak Efficient? Journal of Financial Research, 03. Retrieved from http://en.cnki.com.cn/Article_en/CJFDTotal-JRYJ200103003.htm 